SŁAWOMIR MANDES

ORCID: 0000-0003-2316-8482

Uniwersytet Warszawski

KONSTANTY STRZYCZKOWSKI

ORCID: 0000-0002-7418-4696

Uniwersytet Warszawski

\title{
Wartości na sprzedaż. Budowanie wizerunku marki w mediach społecznościowych ${ }^{*}$
}

DOI: 10.19195/2083-7763.9.16

Założenia, na których opiera się marketing, wciąż ewoluują pod wpływem dynamicznych przeobrażeń. Kryzysy finansowe, niestabilność wzrostu gospodarczego, ekspansja technologii informatyczno-komunikacyjnych, cyfryzacja, konsekwencje ocieplenia klimatu wpływają na zachowania zarówno konsumentów, jak i producentów. Wymusza to okresowe aktualizacje w projektowanych i wdrażanych strategiach marketingowych. Sztafeta organizujących je paradygmatów teoretycznych nie jest oczywiście zjawiskiem nowym. Od lat 50. $\mathrm{XX}$ wieku dokonało się co najmniej kilka zasadniczych reorientacji w podejściu do celów stojących przed marketingiem, ujęciu problemu interakcji z konsumentem, koncepcji oferowanych przez firmę korzyści, rozumieniu wiodących celów marketingowych, definicji rynku i samego produktu. Kierunek zmian określiło przejście od koncentracji na produkcie, realizowane poprzez zorientowanie na konsumenta, do skupienia się na wartościach i kwestiach społecznych (Kotler, Kartajaya, Setiawan 2010). W przekonaniu Philipa Kotlera, Hermawana Kartajaya i Iwana Setiawana (2010) w tej ostatniej fazie noszącej miano marketingu 3.0, dbałość o rentowność firmy zostaje powiązana $\mathrm{z}$ interesem

* Tekst powstał w ramach projektu nr 2016/21/B/HS6/03199 finansowego ze środków Narodowego Centrum Nauki. 
społecznym. Innymi słowy, w proponowanym ujęciu zdobycie przewagi konkurencyjnej wymaga od przedsiębiorstwa ustalenia i sprecyzowania przyświecającej jego działaniom misji o charakterze społecznym, nakreślenia całościowej wizji dotyczącej kroków zmierzających do poprawy warunków życia oraz wartości, z którymi pragnie być kojarzone.

W modelu marketingu 3.0 problemy społeczne postrzega się jako szansę przynoszącą nowe możliwości dla przedsiębiorstwa. Efektem podjęcia tak zdefiniowanych zadań (misja, wizja, wartości) ma być integracja i konsolidacja otoczenia firmy, włączając $w$ to pracowników, dystrybutorów, dostawców, a także jej klientów, zagorzałych fanów oraz sympatyzujących obserwatorów (brand public). Skupienie wokół jednoczącej misji czy idei ma z kolei tworzyć zaczyn przeobrażeń zaznaczających swoją obecność na dwóch płaszczyznach. Na poziomie społecznej praktyki chodzi o przekształcenie wspomnianego środowiska w „zespół” - sieć partnerów aktywnie i dobrowolnie zaangażowanych we współtworzenie i promowanie oferowanego produktu bądź usługi. Na poziomie symbolicznym celem staje się konstrukcja czegoś, co można zdefiniować jako społeczną reprezentację firmy. W swej sztandarowej koncepcji Serge Moscovici (1984) przekonuje, że reprezentacje społeczne powstające na drodze między innymi procesu obiektywizacji stanowią efekt przekształcenia abstrakcyjnych idei w obrazy, postacie, obiekty utożsamiane z niewidoczną treścią. Mają one własną realność, substancję pozwalającą na współkształtowanie rzeczywistości społecznej. Inaczej rzecz ujmując, reprezentacje społeczne stanowią ikoniczną, obrazową odsłonę często złożonych, skomplikowanych idei, koncepcji czy całych teorii. Stają się tym samym ich figuratywnym jądrem, a jednocześnie quasi-bytem zdolnym do samoistnego oddziaływania. Z tego punktu widzenia możemy uznać, że współczesny marketing służy do przekształcenia marki danego przedsiębiorstwa w symbol, metaforę, uchwytny wyraz określonych wartości i idei zmaterializowanych w produktach.

Celem naszego artykułu jest analiza mechanizmów konstruowania wartości na przykładzie marki promowanej przez Ewą Chodakowską, popularną trenerkę fitness, właścicielkę firmy sprzedającej produkty i usługi związane $\mathrm{z}$ aktywnością fizyczną. Na wstępie opiszemy przemiany, jakim podlegały koncepcje marketingu, oraz szerzej opiszemy idee tak zwanego marketingu 3.0. W drugiej części artykułu przeanalizujemy materiał zebrany na stronie facebookowej Ewy Chodakowskiej i zrekonstruujemy mechanizmy językowe oraz symboliczne powiązania produktów z określonym systemem wartości, aby w ten sposób pokazać, jak wygląda proces obiektywizacji abstrakcyjnych treści (w tym wypadku wartości związanych ze zdrowym trybem życia) za pomocą produktów oferowanych przez firmę Ewy Chodakowskiej. 


\section{Marketing oparty na wartościach}

W pewnym sensie to nic nowego. Nie od dzisiaj celem działań marketingowych jest obiektywizowanie marek w świadomości odbiorców przy użyciu wybranych atrybutów, na przykład Volvo - bezpieczeństwo; Apple - kreatywność; Coca-Cola - zabawa; Harley-Davidson — wolność; Levi-Strauss — tradycja itp. W efekcie mają one uzyskać status synonimów owych wartości, ich oczywistych i naturalnych wcieleń. Biorąc jednak pod uwagę wielkie nasycenie rynku, budowanie unikalnej tożsamości marek staje się obecnie zadaniem coraz bardziej utrudnionym. Oznacza to, że oparcie komunikacji z konsumentami na akcentowaniu podobnie ogólnych wartości przestaje być wiarygodne, a przede wszystkim skuteczne. W zaproponowanej koncepcji marketingu 3.0 Kotlerowi i jego współpracownikom chodzi najwyraźniej o coś innego.

Podobnie nie należy wiązać ich propozycji z działalnością filantropijną czy tradycyjnie ujmowaną tak zwaną społeczną odpowiedzialnością biznesu (corporate social responsibility - CSR), w ramach której wspieranie inicjatyw ekologicznych i społecznych stanowi z punktu widzenia przedsiębiorstwa działalność poboczną i w dużej mierze promocyjno-dekoracyjną, nie zaś rdzeń, na którym opiera się model biznesowy firmy. Zresztą tego rodzaju zabiegi coraz częściej zostają rozpoznane przez świadomych konsumentów jako zaplanowana forma manipulacji, przykład cynicznej gry biznesowej, która nie pokrywa się z rzeczywistym działaniem na rzecz dobra wspólnego. Dla autorów nie ulega wątpliwości, że tylko jasno definiując obrany cel i umieszczając go w centrum podejmowanych działań, firmy mogą próbować kreować wartość symboliczną marki jako manifestacji wybranych idei, poglądów i wartości.

W tym ujęciu koncepcja marketingu 3.0 zbiega się ze strategicznym podejściem znanym jako CSV (creating shared value) zaproponowanym przez Michaela E. Portera i Marka R. Kramera (2011) oraz nowymi koncepcjami dotyczącymi społecznej funkcji biznesu - CSR 2.0 Waynéa Vissera (2010) i CSR 3.0 Davida Graysona i Jane Nelson (2013). We wszystkich tych przypadkach napotykamy postulat, by tradycyjną działalność w ramach CSR zastąpić zaangażowaniem posiadanych zasobów w postaci wiedzy i know-how do tworzenia wartości społecznej na drodze operacji ukierunkowanych na uzyskanie wartości ekonomicznej. Inaczej rzecz ujmując, zarówno zaangażowanie firmy w rozwiązywanie najbardziej palących problemów społecznych i ekologicznych, jak również budowanie więzi i współpracy ze społecznościami lokalnymi i sieciowymi staje się tu warunkiem koniecznym do uzyskania przewagi rynkowej. W ten sposób wybrane zadania dotyczące dobra i interesu społecznego oraz propagowane przez firmę wartości mają jej zapewnić możliwość wyróżnienia się na tle konkurencji. Tak opisane podejście radykalnie zmienia dotychczasowy sposób myślenia o produktach, rynkach oraz konsumentach. Misja społeczna wraz z leżącymi u jej podstaw wartościami przeistacza się w motor działalności biznesowej. Jest to odwrócenie 
znanego stwierdzenia Miltona Friedmana głoszącego, że społeczna powinność biznesu sprowadza się do pomnażania zysków.

W swojej pracy Kotler, Kartajaya i Setiawan (2010) opisują trzy stadia ewolucyjne marketingu - 1.0, 2.0 i 3.0. Jak zaznaczają, duża część przedsiębiorstw nadal wdraża w życie jego wcześniejsze wersje. Stąd dające się obserwować asymetrie, nieprzystawalności oraz brak wspólnej, uniwersalnej logiki działania. We wstępnym stadium istnienia, przypadającym na epokę przemysłową, marketing koncentrował się na produkcie. Jego naczelnym zadaniem było przede wszystkim umożliwienie sprzedaży wyprodukowanych towarów. Produkty nie wyróżniały się niczym szczególnym i były przeznaczone dla masowego odbiorcy. Standaryzacja, pseudoindywidualizacja, produkcja taśmowa umożliwiły minimalizację kosztów produkcji, a przez to obniżenie cen wcześniej niedostępnych towarów i włączenie szerszych grup społecznych do grona konsumentów. W erze kapitalizmu informacyjnego sytuacja ulega skomplikowaniu. Dzięki poszerzonemu dostępowi do informacji konsumenci uzyskali możliwość gromadzenia potrzebnych im danych, porównywania ofert, konfrontowania uzyskanej wiedzy i doświadczeń. Nowe technologie komunikacyjne uwidoczniły również, że funkcja i znaczenie masowo wytwarzanego towaru może podlegać adaptacji lub odwróceniu w zależności od jednostkowych potrzeb użytkowników. Stąd konieczność przeprowadzenia w ramach marketingu 2.0 segmentacji rynku i opracowania propozycji produktowej dostosowanej do oczekiwań wybranej grupy docelowej. Z jednej strony przyniosło to większe niż dotychczas skupienie się na potrzebach konsumenta wraz z nasileniem zabiegów zorientowanych na zdobycie jego lojalności, z drugiej zaś ugruntowało przekonanie, że rola konsumenta zasadniczo sprowadza się do pozostawania biernym obiektem lepiej lub gorzej przygotowanych kampanii marketingowych. Ten stan rzeczy zmienia się pod wpływem nowych postaw ujawniających się wśród konsumentów. Ich cechą wspólną staje się krytyczny stosunek do rzeczywistości, dystans i brak zaufania do tradycyjnej reklamy, korporacji i języka marketingowego. Towarzyszy im jednocześnie dążenie do wspierania marek, które w przekonaniu użytkowników pozostają autentyczne, wdrażają w życie to, co głoszą, a przez to są godne zaufania ${ }^{1}$.

${ }^{1}$ Według badania z 2014 roku przeprowadzonego przez MSL Group w 17 krajach, dla 79\% Polaków urodzonych między rokiem 1980 i 2000 szczególnie istotne jest, by biznes angażował się w działania na rzecz dobra wspólnego (ochrona środowiska, ochrona zdrowia, poprawa sytuacji gospodarczej). 73\% spośród wszystkich badanych stwierdziło, że rządy poszczególnych krajów nie potrafią poradzić sobie z najważniejszymi wyzwaniami wynikającymi ze zmian klimatycznych, zagrożeń dla zdrowia, globalnej sytuacji ekonomicznej. Aż 83\% z nich oczekuje zwiększenia aktywności biznesu w tym zakresie. Co więcej, 74\% polskich badanych stwierdziło, że firmy powinny również angażować się w działania zmierzające do poprawy kondycji i samooceny młodych ludzi (dla porównania w ujęciu globalnym odsetek ten wyniósł 59\%). 51\% wszystkich ankietowanych zadeklarowało chęć osobistego uczestnictwa w inicjatywach, których celem jest rozwiązywanie problemów współczesnego świata, a 69\% spodziewało się od swoich pracodawców umożliwienia im 
Nowi, refleksyjni konsumenci poszukują firm, które wyrażają i realizują cele odpowiadające ich poczuciu sprawiedliwości społecznej, ekonomicznej i środowiskowej. W wyłaniającym się podejściu oferowany na rynku produkt winien wpisywać się w ogólną ramę nakreśloną przez zespół podzielanych przez konsumenta norm i wartości. Odpowiedzią na tego rodzaju społeczne oczekiwania jest marketing 3.0, wpisujący dążenie do zaspokojenia potrzeb konsumenta w szerszy projekt udoskonalania świata, działań ukierunkowanych na dostarczenie rozwiązań najbardziej żywotnych problemów i odpowiadającego ludzkiej chęci bycia w zgodzie z wyznawanymi wartościami. Jak wyjaśniają Kotler, Kartajaya, Setiawan (2010, s. 19), marketing w wersji 3.0 „wynosi koncepcję marketingu na poziom ludzkich aspiracji, wartości i ducha”. Tym samym uzupełnia dotychczasowy marketing doświadczeń i marketing emocjonalny o elementy inżynierii społecznej, psychoterapii oraz animacji kultury (Giza 2017, s. 212). Autorzy reprezentują mocne przekonanie, że czynnikiem wyróżniającym dla firmy jest jej kapitał $\mathrm{w}$ postaci propagowanych wartości. W warunkach ciągłej zmiany to one mogą zapewnić mocną i wyróżniającą pozycję przedsiębiorstwa. Należy jednak podkreślić, że przyjęcie proponowanego przez nich podejścia nie jest kwestią dobrej woli przedsiębiorców. Oprócz oczekiwań społecznych zmianę w polityce firmy wymuszają również przeobrażenia na poziomie technologii. $\mathrm{O}$ ile marketing 1.0 odpowiadał wymogom epoki industrialnej i wysokonakładowej produkcji zestandaryzowanych produktów, a marketing 2.0 wiązał się z pojawieniem się technologii komunikacyjno-informacyjnych umożliwiających dopasowanie zróżnicowanej oferty produktowej do potrzeb wybranych grup docelowych, o tyle katalizatorem marketingu 3.0 jest pojawienie się mediów społecznościowych (Facebook, Twitter, YouTube) wraz z technologiami pozwalającymi na samodzielne generowanie treści (idei, informacji, rozrywki, oprogramowania) i oddolną współpracę pomiędzy użytkownikami sieci. W największym skrócie, technologia nowych mediów pozwoliła konsumentom na przeistoczenie się w aktywnych prosumentów. Równocześnie zrewolucjonizowała zachodzącą między nimi komunikację, umożliwiając dzielenie się osobistymi opiniami i doświadczeniami na globalną skalę. W praktyce przyniosło to wyraźne zmniejszenie się możliwości korporacyjnego modelowania zachowań konsumenckich przy użyciu tradycyjnej reklamy. Oczywiście pojawienie się portali społecznościowych przyniosło niespotykane dotąd możliwości zbierania danych, profilowania konsumentów oraz projektowania komunikacji marketingowej. Jednak dotycząca produktów i producentów globalna wymiana informacji zachodząca $w$ ramach horyzontalnych połączeń pomiędzy klientami położyła kres skłonności firm do traktowania ich jako zbioru odizolowanych monad, których głos można ignorować. Stąd pojawiająca się konieczność zaproponowania nowej płaszczyzny porozumienia z konsumentami i zaangażo-

podjęcia działań na rzecz wspólnego dobra, http://news.mslgroup.pl/pr/287392/millenialsi-oczekuja-wiekszego-zaangazowania-biznesu (dostęp: 20.12.2018). 
wania ich na rzecz wartości, do reprezentowania których firmy pretendują (vide korporacje zajmujące obecnie stanowiska $\mathrm{w}$ kontrowersyjnych społecznie tematach, na przykład Levi-Strauss w kwestii ograniczenia dostępu do broni palnej, Nike w kampanii przeciwko policyjnej przemocy wobec Afroamerykanów).

W dalszej części artykułu przeanalizujemy wyniki badania strategii marketingowej Ewy Chodakowskiej prowadzonej za pomocą profilu na Facebooku. Jego właścicielka jest trenerką fitness, specjalizującą się w treningu funkcjonalnym, firmującą swym nazwiskiem liczne produkty kojarzone z segmentem fitness. Głównym narzędziem komunikacji, promocji i sprzedaży oferowanych przez nią produktów jest strona internetowa http://ewachodakowska.pl, na której możemy znaleźć odsyłacze do sklepu, kanału streamingowego oraz wspomnianego profilu na Facebooku, co wskazuje, że profil ten jest jednym z filarów jej przedsięwzięcia biznesowego i podstawowym środkiem komunikacji z klientkami i klientami. W jego opisie została umieszczona lista efektów, które potencjalna klientka osiągnie dzięki proponowanym ćwiczeniom, krótki opis ćwiczeń oraz przypomnienie, że „sukces składa się nie tylko ze skutecznego treningu, ale również z regeneracji i ZDROWEJ DIETY"2. W tym kontekście zdjęcie profilowe Ewy Chodakowskiej należy odczytać jako domyślną ilustrację rezultatów, które można osiągnąć dzięki nabyciu programu treningowego. W zakładce znajduje się również krótki opis zasad dostępu do kanału streamingowego oraz korzyści wynikających z jego subskrybowania. Zarówno opis programu, jak i opis kanału jest sformułowany w postaci bezpośredniego przekazu skierowanego do konkretnego odbiorcy: „Masz w tym czasie nieograniczony dostęp”, „Rozwijamy się DLA CIEBIE”, „Rzuć okiem i daj znać jak się podoba”, „Z HOT BODY: spalisz [...], zniwelujesz [...]”, „Zwróć uwagę aby wszystkie ćwiczenia wykonywać poprawnie”. Całość komunikacji jest przemyślana, spójna i nastawiona na: a) promocję wizerunku Ewy Chodakowskiej, która jest marką całego przedsięwzięcia, b) promocję kluczowych produktów jej firmy.

Facebookowy profil Ewy Chodakowskiej ma charakter publiczny. Materiały były zbierane w okresie od 4 grudnia do 16 grudnia 2017 roku. Wykorzystany w poniższym tekście materiał został zebrany w postaci zrzutów z ekranu zapisanych w specjalnym programie do zapisywania tego rodzaju danych. Każdorazowo zapisywano post główny oraz wszystkie znajdujące się pod nim wpisy dwa dni po jego umieszczeniu. Zebrany materiał był następnie analizowany $\mathrm{z}$ wykorzystaniem programu Atlast.ti. Przedmiotem analizy była zawartość postów głównych, sposób ich ramowania, wykorzystane do promocji wartości.

${ }^{2}$ https://www.facebook.com/chodakowskaewa (dostęp: 20.12.2018). Jeśli nie podano inaczej, przytoczone cytaty pochodzą z tego samego źródła. W cytatach zachowano oryginalną pisownię. 


\section{Budowanie wartości w komunikacji marketingowej - analiza profilu facebookowego Ewy Chodakowskiej}

W badanym okresie na profilu pojawiło się 30 postów o następującej tematyce: a) list od zadowolonej klientki, b) dieta, c) tematy ad hoc, d) promocja produktów. W udostępnianym na profilu przekazie dominowały posty, które roboczo można nazwać „listem od zadowolonej klientki”. Ich struktura była stała i w zasadzie niezmienna. W jej skład wchodziły:

- Wprowadzenie (mowa motywacyjna), w którym przedstawia się autorkę przesłanego na adres profilu maila. Wprowadzenie takie zazwyczaj utrzymane jest $\mathrm{w}$ formie bezpośredniej (ja - Ewa Chodakowska, wy - użytkowniczki, fanki profilu). Standardowo zawiera ono odniesienia do wartości, to jest sukcesu, szczęścia, zmiany (metamorfozy), pracy, walki, i służy ramowaniu treści maila. Wprowadzenie kończy się wezwaniem do reakcji (wyzwalaczem) nawołującym do „zostawienia lajków”, wyrażenia wsparcia, udzielenia pochwały autorowi listu, na przykład: „Zostaw lajka dla Marzeny, na pewno się ucieszy i zabieraj się za swoją metamorfozę"; „Zostaw lajka dla Gosi. tez na jej miejscu byłoby Ci miło i zabieraj się do pracy..”; „Na zachętę wrzucam metamorfozę 4-miesięczną zostaw kciuka dla zalatanej mamy dwójki dzieci W na pewno będzie Jej miło?? i zabieraj się za swoje wyzwania”; „zostaw lajka dla Kasi i zasuwaj na matę”; „Zostaw dla Niej lajka aaa !! Milion lajkow parę słów otuchy.. gratulacji..”; „zostaw lajka dla Patryka i dwa słowa uznania..NA PEWNO SIĘ UCIESZY”; „Zostaw lajka dla Aneczki i sama zabieraj się za swoje marzenia Ty tez dasz radę". Jak się wydaje, jest to szczególnie ważny element rozwijanej komunikacji, ponieważ aktywizuje zbiorowość do działania, co z kolei z uwagi na jego widoczność (lajki, komentarze, tagowanie, udostępnienia) w ramach portalu, automatycznie przekłada się na upowszechnienie wiedzy o profilu Chodakowskiej i zwiększenie jego zasięgu.

- Prom ocja produktu. Po wprowadzeniu w poście umieszczona zostaje krótka informacja dotycząca dostępnych programów treningowych i dietetycznych. Jej treść w badanym okresie w każdym poście była identyczna.

- List od użytkowniczki. Co ciekawe, zazwyczaj nie pojawia się w nim odniesienie do produktu, konkretnego programu ćwiczeniowego czy dietetycznego. Brak w nim też opinii wyrażających bezpośrednio satysfakcję $\mathrm{z}$ ich zastosowania. List zawiera przeważnie osobiste podziękowanie skierowane pod adresem Ewy Chodakowskiej oraz krótszą ( 5 zdań) lub dłuższą (do 15 zdań) historię opisującą przebytą przemianę (life-changing story) ${ }^{3}$.

- Zdjęcie, a dokładnie dwa zestawione zdjęcia: przed i po „metamorfozie". Na zdjęciach widoczna jest $\mathrm{z}$ reguły nakładka - białe litery na czarnym tle

${ }^{3}$ Life-changing stories są też wykorzystywane jako materiał promocyjny w postaci materiałów video, w których klientki opowiadają własne historie. Można je oglądać nieodpłatnie na http:// beactivetv.pl/filmy/fajterki (dostęp: 20.12.2018). 
— z napisem: „dieta BE DIET na bebio.pl”. Wybrane zdjęcia użytkowniczek są również dostępne na stronie http://beactivetv.pl/strona/wasze-metamorfozy jako widomy dowód skuteczności oferowanego przez firmę produktu. Obok pracy komunikacyjnej w postaci komentarzy, polubień, udostępnień, oznaczeń, zdjęcia te stanowią niewątpliwie najważniejszy, dobrowolnie udostępniany wkład konsumentów w działania marketingowe firmy.

Wpisy poświęcone diecie zawierają konkretne zdrowe, dietetyczne przepisy kulinarne. W wypadku analizowanego materiału były to przepisy świąteczne. Poza promocją zdrowego odżywiania ich celem była również promocja jednego z oferowanych produktów w postaci zestawów dietetycznych bądź batonów energetycznych. Dodatkowo, podobnie jak w przypadku postów typu „list od zadowolonej klientki”, stanowiły one okazję do aktywizowania osób śledzących profil i skłonienia do podjęcia zadań o charakterze komunikacyjno-promocyjnym, na przykład:

Coś pysznego na ząb! dla Ciebie i Twoich maluchów, Aromatyczne przepisy fruną saniami do Ciebie! U d o s t ę p n i j - przydadzą się na święta;

JELOOOOOŁ, a co Ty dzisiaj wsuwasz na śniadanie? Czekam na foto i może przepis. Poniżej świeżutka LISTA ZAKUPÓW na ostatni tydzień naszego WYZWANIA. Owsianka z amarantusa i kulki cynamonowe BE RAW idealne połączenie;

BABECZKI JADŁOSPIS WIGILIJNY gotowy Kolejne dni będę wrzucać na bieżąco Przyda się? Zostaw lajka i udostępnij., bo do jutra może przepaść w natłoku innych postów;

Jadłospis świąteczny jest już gotowy Część potraw, które uwzględniłam w jadłospisie wigilijnym, (patrz - wczorajszy post ) będzie wykorzystana w Boże Narodzenie i przez kolejne dwa dni Mniej pracy dla Ciebie, więcej czasu dla rodziny i przyjaciół Udostępnij na swój Profil, tym samym będzie Ci łatwiej wrócić do tego jadłospisu. W innym razie może się zagubić wśród innych postów;

Mam dla Ciebie szybkie ciasteczka, które będą ciekawym urozmaiceniem świątecznego stołu.. Udostępnij, nie zgub, mogą się przydać nie tylko w okresie świątecznym ${ }^{4}$.

Wpisy ad hoc przykładowo zawierały: komentarz w sprawie domniemanego konfliktu z Anną Lewandowską, informacje na temat akcji charytatywnych, ostrzeżenie przed podróbkami produktów sygnowanych przez Ewę Chodakowską, wspólne zdjęcie i wyrazy uznania dla Martyny Wojciechowskiej, zdjęcie trenerki śpiącej na macie po ukończonym treningu, zdjęcie zachodu słońca $\mathrm{z}$ wakacji na Dominikanie. Treść postów ad hoc nie ma wspólnego mianownika, poza chęcią przedstawienia wybranych zdarzeń, problemów z życia Chodakowskiej, którymi zdecydowała się podzielić, oferując tym samym „intymny” wgląd w jej życie i stany emocjonalne. Wpisy ad hoc uwidaczniają też funkcję profilu jako kanału

\footnotetext{
${ }^{4}$ Pisownia i podkreślenia oryginalne.
} 
służącego do szybkiej interwencji w sytuacjach kryzysowych (plotki, pojawienie się podróbek). Można też traktować je jako sposób na przełamanie monotonii dominujących wpisów i wprowadzenie elementu autentyzmu i spontaniczności w komunikacji z klientkami.

Ogólnie rzecz biorąc, główną tematyką postów udostępnianych na profilu są produkty firmy. Rytm publikowania postów, ich organizacja, opracowanie wizualne wskazują na zaawansowaną profesjonalizację profilu. Powstaje pytanie, czy i w jakim stopniu Ewa Chodakowska kontroluje treści udostępniane na jej stronie, a w jakim jest to efekt przemyślanej strategii? W wywiadach ${ }^{5}$ zapewnia, że sama redaguje pojawiające się tam wpisy. Biorąc pod uwagę ich spontaniczny charakter (posty ad hoc), potoczność użytego języka, zróżnicowaną edycję, błędy deklinacyjne i stylistyczne można przyjąć, że rzeczywiście niektóre z nich publikuje samodzielnie i spontanicznie. Pośrednio potwierdzają to również jej - dość rzadkie, acz regularne - wpisy pod komentarzami użytkowniczek śledzących profil. Jednak powtarzalność niektórych typów postów oraz dopracowana edycja sugeruje, że są one przygotowane przez inne osoby zgodnie ze strategią firmy. Budowanie relacji z użytkowniczkami i prezentowane wartości są podporządkowane celowi nadrzędnemu: sprzedaży produktów na podstawie life-changing stories bohaterek korespondencji przesyłanej na profil marki.

Treść postów typu „list od zadowolonej klientki” ma zazwyczaj binarną strukturę: treści zawarte we właściwych, przytoczonych — jak się wydaje bez skrótów i edycji - mailach oraz poprzedzający je komunikat motywacyjny zawierający wprowadzenie i ramę interpretacyjną treści postu. Zdarza się jednak, że przesłanką do wygłoszenia tego rodzaju komunikatu nie jest mail od użytkowniczki, lecz inna, wybrana ad hoc okazja (w badanym okresie: zdjęcie z Martyną Wojciechowską, podsumowanie kończącego się roku). W prawie każdym przypadku publikowany wpis zawierał zachętę do zakupu głównych produktów firmy w postaci programu treningowego i planów dietetycznych dostępnych na stronie internetowej. Treści zawarte w postach „list od zadowolonej klientki” można podzielić na dwie grupy: podziękowania oraz z life-changing story. W przebadanym okresie spośród udostępnionych na profilu postów sześć zawierało, wyrażone w rozmaity sposób, podziękowania dla Chodakowskiej oraz emocjonalne pochwały dotyczące jej energii, charyzmy i autentyczności. Następnie we wpisach pojawiała się szczegółowa informacja odnośnie do efektów podjętych ćwiczeń w postaci spadku masy ciała, na przykład: „Ewunia chciałam ci bardzo podziękować tyle serca, pięknych słów motywacji i mega pozytywnej energii dostałam na tych szaleńczych warsztatach ze pieje z zachwytu” (p13); "Jesteś naprawdę osobą która daje wielkiego kopa

\footnotetext{
${ }^{5}$ https://www.youtube.com/watch?v=KcxgVCr4_IE\&t=1s (dostęp: 20.12.2018).
} 
w dupę za lenistwo !:)) To jeszcze nie koniec, bo walczę jeszcze o 10 kilo ale wierze że będzie już tylko lepiej! Dziękuję i kocham" (p24).

Tego typu wiadomości od klientek są dla Chodakowskiej podstawą do wyrażenia ogólnej myśli - filozofii życia, której egzemplifikacją jest autorka maila. Przykładowo jeden z przytoczonych powyżej maili został poprzedzony następującym komentarzem: „Marzenka i Jej NOWE CIAŁO, ale czy tylko ciało? Zobacz ile pewności siebie jest w tym ciele na zdjęciu nr 2? Zostaw lajka dla Marzeny, na pewno się ucieszy i zabieraj się za swoją metamorfozę" (p24). Pozostałe maile zawierają historie (life-changing story) dotyczące przebytej transformacji, jaka stała się udziałem ich autorek. Najczęściej są to krótkie opowieści opisujące trudności w dążeniu do wymarzonej smukłej sylwetki, poprawy stanu zdrowia i własnej samooceny. Trudności te mogą mieć naturę wewnętrzną, na przykład związaną z zaburzeniami odżywania, problemami z motywacją, utrzymaniem samodyscypliny, lub zewnętrzną - odnoszącą się do obciążenia pracą, obowiązkami domowymi, kłopotami w relacjach z partnerami. Nie brakuje jednak historii traktujących o całościowej, nie tylko fizycznej zmianie, na przykład:

Przede mną jeszcze trochę pracy, ale dzięki temu, że zrozumiałam, że te zmiany są na całe życie przestałam się spieszyć. Wiem, że powoli dotrę do celu a teraz pomaga mi w tym dieta bebio. Zanim zaczęłam dbać o siebie cierpiałam na okropne problemy z kręgosłupem... pewnego dnia powiedziałam sobie, że nie pozwolę aby ból rządził moim życiem! Od tego czasu schudłam ok $20 \mathrm{~kg}$, wyzdrowiałam, zdobyłam nowe wykształcenie oraz nowa karierę. Jestem trenerka osobista, dzięki czemu mogę pomagać oraz inspirować innych, poznałam cudownych ludzi oraz niesamowitego człowieka, którym jest mój narzeczony, to wszystko dzięki jednemu postanowieniu, ze się nie poddam. Nie wolno się poddawać, zawsze możemy zacząć od nowa (p7).

Wszystkie prezentowane na profilu historie poprzedza wstęp, w którym Chodakowska w sposób ogólny definiuje zawarte w nich wartości i wykonuje pierwszy krok w stronę ich obiektywizacji w oferowanych przez nią produktach. Tego rodzaju zabieg na dwa ogólne sposoby ukierunkowuje ich interpretację. Po pierwsze, przez odniesienie treści maila do jednej lub dwóch wybranych wartości, po drugie, przez wezwanie do afirmacji (polubienie, komentarz) zaprezentowanej historii i przekazu, jaki niesie. Zależność pomiędzy wykorzystanymi ramami a treścią listu od zadowolonej klientki przedstawia tabela 1.

Zebrany materiał jest zbyt ubogi, aby można było z całą pewnością orzec, czy zachodzi ilościowy związek między treścią maila a jego ramowaniem. Wydaje się jednak, że listy od klientek stanowią jedynie pretekst do zdefiniowania i afirmacji wartości przyświecających marce o nazwie Ewa Chodakowska. 


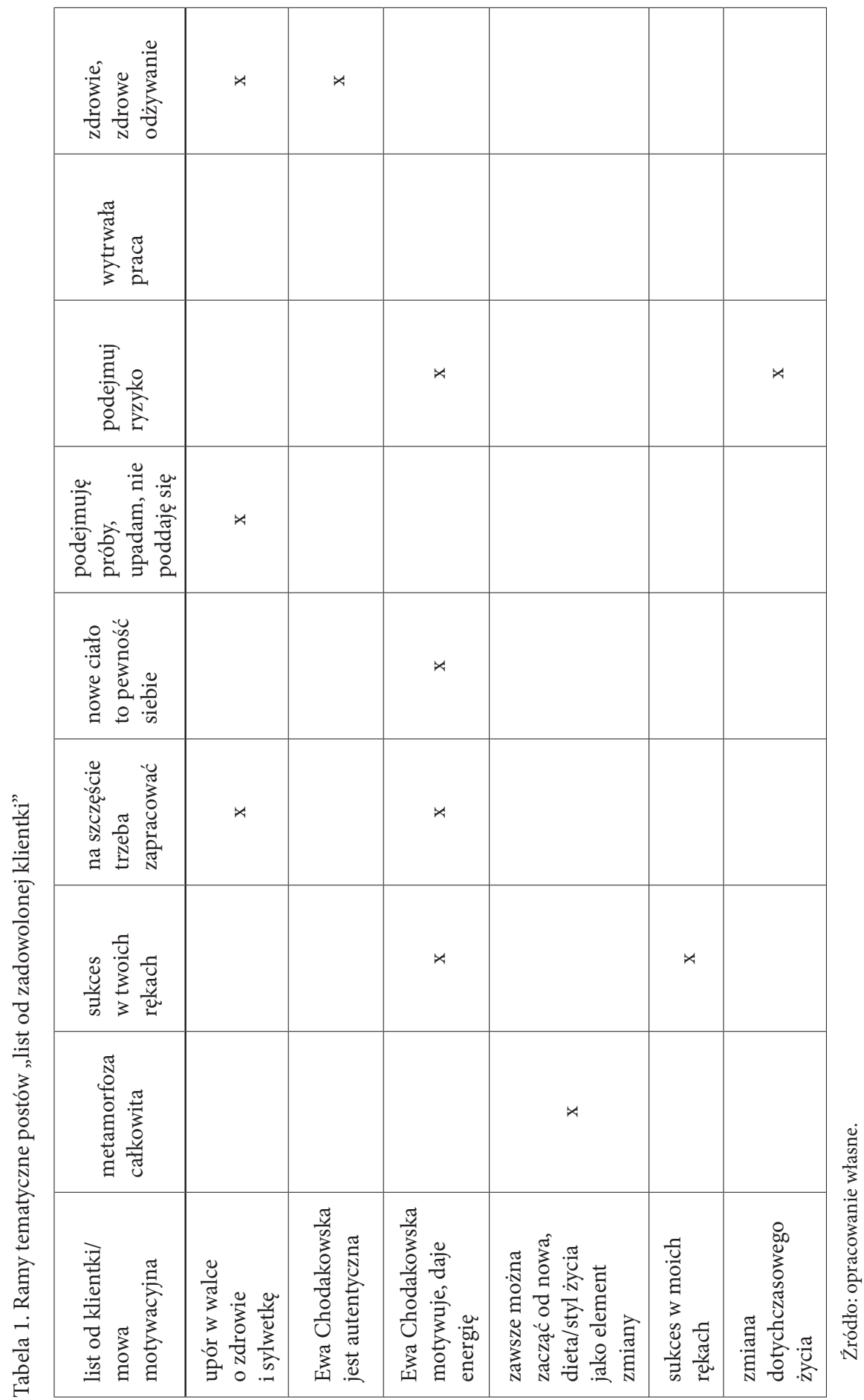


Podstawową wartością promowaną przez Ewę Chodakowską jest metamorfoza. Pojęcie metamorfozy występuje w trzech komplementarnych sensach, a ich złożenie pokazuje wzorcowy sposób utożsamienia produktu z wartością, oparty na poszerzeniu semantycznego pola znaczeniowego słowa. W sensie podstawowym metamorfoza jest nazwą własną programu treningów promowanych w następujący sposób:

Trening funkcjonalny przy użyciu piłki (w programie pokazane są też wersje ćwiczeń bez piłki). Spalisz MAKSYMALNĄ ilość kalorii, zredukujesz tkankę tłuszczową "i wymodelujesz sylwetkę" EFEKT METAMORFOZY już po 21 dniach!!! Trenując regularnie poprawisz koordynację ruchową i postawę ciała - dwa kluczowe aspekty skutecznego treningu. Ćwiczenia zawarte w tym programie nie tylko sprawią, że osiągniesz zamierzone efekty — dzięki nim będziesz pracować również nad jakością Swojego życia! ${ }^{6}$

W powyższym opisie metamorfoza jest rozumiana wąsko jako fizyczna przemiana polegająca na spalaniu tkanki tłuszczowej. Jednak Chodakowska wykorzystuje również pojęcie metamorfozy do opisywania zmiany, która następuje w życiu osoby rozpoczynającej ćwiczenia fizyczne i modyfikującej nawyki żywieniowe. W tym drugim ujęciu metamorfoza oznacza transformację stylu życia i związanych z nim praktyk. W sposobie ramowania maili można wyróżnić jeszcze trzecią warstwę sensów odnoszących się do przemiany tożsamości obejmującej nie tylko styl życia, ale również odgrywane role społeczne:

Dieta BE DIET.. - 20 kg.. nowe ciało., nowa praca., nowe życie.. Zostaw lajka dla Aneczki i sama zabieraj się za swoje marzenia” (p7); „BEBA wygrała parę lat temu uczestnictwo w moim Tygodniu Metamorfozy [...] KOBIETA nie zwalnia tempa i wygląda jak MILION DOLARÓW zmieniła ciało., umysł., życie., męża przystojniakiem, który próbuje dotrzymać Jej tempa na treningach.. (p31).

W tym miejscu warto podkreślić, że metamorfoza w trzecim sensie oznacza przebudowę relacji z innymi ludźmi w sferze prywatnej i zawodowej, nowy początek $\mathrm{w}$ innym środowisku społecznym i z nowym nastawieniem do życia i świata. Metamorfoza w tym sensie nie jest celem, lecz jest wskazana jako możliwy skutek konsekwentnego wdrożenia zaleceń Chodakowskiej. Na pozostałe ramy można spojrzeć jako na uszczegółowienie ogólnej obietnicy metamorfozy. W poszczególnych postach dowiadujemy się: „Co dzięki metamorfozie można osiągnąć? Nowe ciało, które daje pewność siebie” (p24) oraz „zdrowie i zdrowe nawyki odżywania" (p1, p3). Co trzeba zrobić by przejść metamorfozę? Przede wszystkim "przestać się bać i podjąć ryzyko” (p11), „zacząć ćwiczyć, zmienić dietę. I uwierzyć, że sukces jest w twoich rękach" (p19, p25). Zmiana nastawienia jest tu pierwszym koniecznym krokiem: „Jeśli chcesz... jeśli tak głęboko, szczerze chcesz., nic nie stanie Ci na przeszkodzie!! Sukces JEST W TWOICH RĘKACH!” (p19).

Sama zmiana nastawienia jednak nie wystarczy. Niezbędna jest również „wytrwała praca" (p37). Motyw pracy jest $\mathrm{z}$ tego punktu widzenia bardzo istotny

${ }^{6}$ https://sklep.bebio.pl/plyta-metamorfoza-pilka-beactive (dostęp: 20.12.2018). 
i wydaje się dominować w wypowiedziach klientek. Sama Chodakowska nie odwołuje się do niego zbyt często (przynajmniej w przebadanym okresie), choć, jak stwierdza: „Co mylisz patrząc na takie metamorfozy? [...] każda z Was ma RÓWNE SZANSE., tutaj nic się nie udaje tutaj WSZYSTKO jest kwestią WYTRWAŁEJ PRACY" (p37). Powyższy cytat pokazuje też, że praca jest przedstawiona jako źródło sprawczości, w które zaopatrzona jest każda $\mathrm{z}$ użytkowniczek. Wystarczy z niego zaczerpnąć, zacząć pracować i można osiągnąć to, co się chce. $\mathrm{Z}$ tej perspektywy praca upodmiotawia człowieka, wyposaża go w sprawczość umożliwiająca mu dokonanie zmiany w swoim życiu:

Na co czekasz? Aż coś się wydarzy? Szczęście nie przychodzi i nie puka ot tak do naszych drzwi.. To nie jest przypadek. Szczęście mamy wszyscy w naszych rękach.. Wykorzystaj to co masz i zapracuj na to co chcesz mieć.. (p13).

Warto zwrócić uwagę na zaskakującą konstrukcję stylistyczną powyższego cytatu, z którego wynika, że szczęście już mamy w rękach, choć trzeba jeszcze zapracować na to, co się chce mieć. Możliwość pracy jest szczęściem, reszta to tylko konsekwencja i wysiłek. Wizja metamorfozy wyłaniająca się z powyższej rekonstrukcji zastosowanych ram jest jasna: każdy jest zdolny zmienić swoje życie, każdy ma narzędzia, aby tego dokonać, jeśli tylko jest zdolny do pracy, do wysiłku. Jednocześnie jednak Chodakowska nie jest bezwzględnym sędzią niewybaczającym słabości. $\mathrm{W}$ jednym z postów przyznaje:

i oczywiście na raport akcji CUKIER STOP. Dałaś radę? Ja parę razy poległam., ale nie przestaje podejmować kolejnych prób. Taka nieskończona liczba „spróbuje raz jeszcze”, to tez pewna forma regularności (p16).

Przyznając się do słabości, Chodakowska wykazuje się jednocześnie zrozumieniem dla siebie i dla swoich klientek, które często uskarżają się na własne odstępstwa w dążeniu do wyznaczonego celu. Upadek, podnoszenie się i podążanie dalej zostaje w ten sposób wpisane w proces metamorfozy. Chodakowska, przyznając się do słabości, ułatwia identyfikację ze swoją osobą, ikoną produktów i metamorfozy w każdym z jej trzech sensów. Jako marka Chodakowska uzyskuje dzięki temu rys ludzki, humanistyczny, upodobniający ją do jej fanek. Tym samym zakres łączących je elementów wykracza poza wspólnotę wartości, obejmując również osobiste przywary i indywidualne potknięcia.

Wśród analizowanych postów znalazły się również takie, w których Chodakowska wyraża promowane przez siebie wartości bez odniesienia do historii klientek. Miało to miejsce trzykrotnie. W pierwszym z postów podkreśla się znaczenie codziennych wyborów:

Skoncentruj się na tu i teraz, dając z siebie wszystko co najlepsze masz do zaoferowania., tak żeby być za 10 uśmiechniętą .. mądrzejszą., dojrzalszą., bardziej cierpliwą i wyrozumiałą Kobietą Nie musisz wiedzieć co będziesz wtedy robić, gdzie będziesz wtedy mieszkać, jak będzie wyglądał Twój dzień.. Ważne jest, żebyś dziś i jutro dokonywała właściwych wyborów, na drodze do zdrowia i sprawnego ciała (p1). 
Powyższe przesłanie można zinterpretować na co najmniej dwa sposoby. W najprostszym ujęciu jest to wezwanie do wyboru oferty Ewy Chodakowskiej, która gwarantuje osiągnięcie zamierzonych celów. Jednak bezpośrednie odniesienie do oferowanych produktów nie pojawia się w poście. Towarzyszy mu tylko zdjęcie uśmiechniętej Chodakowskiej na plaży w stroju bikini. W głębszym sensie jest to wezwanie do świadomego życia - refleksyjności - do przemyśliwania swoich wyborów dietetycznych i życiowych tu i teraz, do bardziej świadomego życia. Podobnie można odczytać sens następnego wpisu zawierającego wezwanie do noworocznych podsumowań:

Jeżeli coś nie poszło po Twojej myśli, przegadaj to ze sobą.. Przy czym pamiętaj nigdy nie przestawaj być dla siebie dobrą̨.. [...] W przyszłym roku postaraj się o : rozwój osobisty..życie w zgodzie ze swoimi wartościami, bycie obecnym tu i teraz tak ważne dzisiaj.. zaangażowanie w pasje, realizowanie obranych celów, spełnianie marzeń małych i dużych, pozytywnych ludzi wkoło.. Przelej myśli na kalendarz..Zaplanuj rok 2018..i ciesz się każdym najmniejszym sukcesem (p15).

Tym samym Chodakowska podsuwa swoim odbiorcom proste narzędzie do wyrażenia i uporządkowania swoich wartości - kalendarz, jak można przypuszczać, na nadchodzący rok, w którym ma zostać zapisana i zachowana lista priorytetów. Co ciekawe, po wezwaniu do przemyślenia własnych celów, autorka nie pozostawia miejsca na ich wybór, tylko od razu dostarcza gotową ich listę do umieszczenia w kalendarzu. Na jej pierwszym miejscu znajduje się rozwój osobisty. Nie jest jasno powiedziane, czy ta pierwsza pozycja ma jakieś szczególne znaczenie. Wydaje się jednak, że wszystkie pozostałe są podporządkowane tej wartości ze względu na jej najbardziej ogólny charakter. Opisana lista priorytetów nie jest jedyną. Przy wpisie poświęconego spotkaniu ze znaną celebrytką, podróżniczką Martyną Wojciechowską (który jak można zakładać ma charakter czysto promocyjny, służący wzajemnemu udostępnieniu posiadanych publiczności i zwiększeniu zasięgu przekazywanych treści na $\mathrm{Fb}$ ) znajdujemy jeszcze jedną:

Ludzie szczęśliwi, pewni siebie i pracujący na własny sukces wyróżniają się pewnymi cechami: chcą sukcesów innych i wspierają ich, nie życzą nikomu porażki, nie boją się zmiany, nie trzymają urazy, potrafią przyznać się do swoich błędów, służą dobrą radą innym, stale uczą się nowych rzeczy. Świat jest tak duży, że znajdzie się miejsce dla każdego marzenia, sukcesu, szczęścia i pomysłu na siebie! (p38)

Rozpatrując łącznie opisane powyżej posty, wyróżnić można dwie ogólne wartości organizujące ramowanie i poszczególne listy. Po pierwsze, jest nią wspominana już refleksyjność. Realizacja metamorfozy wymaga ciągłego monitorowania swojego zachowania i rozpatrywania go w kategoriach dokonywanych wyborów. Po drugie, indywidualizm przejawiający się w przekonaniu, że każdy musi samodzielnie rozważyć i określić swoje priorytety. Ani żadna instytucja, ani żadna grupa (na przykład rodzina) nie są wskazane jako punkty odniesienia, które trzeba uwzględnić podczas ich precyzowania. Chodakowska nie neguje ich znaczenia, nie wzbrania uwzględniania różnych odniesień, jednak to decydująca jednostka 
musi rozstrzygnąć, czy chce je brać pod uwagę i w jakim zakresie. Indywidualizm przejawia się również $\mathrm{w}$ przekonaniu, że istnieje wiele możliwych wyborów i wszystkie są równie dobre, równie dostępne dla wybierającej jednostki. Każdy może wybierać. To czyni nas szczęśliwymi. Pluralizm wartości przedstawia się w optymistycznej postaci. Wartości jawią się jako komplementarne lub przynajmniej niesprzeczne, a poszczególne wybory nie niosą większych konfliktów. Nie ma o nich mowy ani w publikowanych postach Chodakowskiej, ani w listach od zadowolonych klientek. Nie znajdziemy ich również w komentarzach pojawiających się na profilu. $Z$ tego punktu widzenia interesująca jest druga przytoczona lista, sugerująca, że jedynym problemem, z jakim możemy się zetknąć, jest nieżyczliwość ludzka oraz zaniechanie świadomych działań zmierzających do zmiany dotychczasowego życia. Prezentowany indywidualizm nie jest bynajmniej synonimem aspołeczności, nie przejawia się w odrzuceniu innych, izolacji. Wręcz przeciwnie. Chodakowska zachęca do wzajemnej życzliwości i pomagania innym. Przypomina jednak, że wybory podejmujemy zawsze na własny rachunek, a ostateczną instancją, przed którą za nie odpowiadamy, jesteśmy my sami.

Wchodząc na jeszcze wyższy poziom abstrakcji, można powiedzieć, że osią organizującą refleksyjność i indywidualizm jest w badanym obszarze opozycja na linii bierność vs. aktywność. Chodakowska nie proponuje żadnej metody refleksji nad swoim życiem, nie zachęca nawet wprost do refleksji. Charakterystyczne, że pisze, aby pewne sprawy „ze sobą przegadać”, a nie przemyśleć. Jeśli zachęca do skupienia się na własnych potrzebach, to kwestię otaczających jednostkę ludzi całkowicie pomija. Nie podsuwa też konkretnych recept na ułożenie sobie życia rodzinnego czy zawodowego. Jak możemy wnioskować, wszystko się ułoży pod warunkiem, że bierność zastąpi aktywność, a uleganie lenistwu, zaleganie przed telewizorem, zajadanie się „śmieciowym” jedzeniem ustąpi miejsca aktywności fizycznej (ćwiczenia) i poznawczej (świadomość tego, co się je). Zainicjowana zaś w sferze fizycznej aktywność przełoży się na aktywność w innych obszarach z równie dobrymi skutkami.

Zdrowe żywienie, z ćwiczeniami, stanowi główny filar programu metamorfozy według Chodakowskiej. Poza batonikami, które można kupić na terenie całej Polski, na stronach firmy są dostępne specjalnie przygotowane programy żywieniowe. Produkty spożywcze stanowią jednak małą część asortymentu firmy. Dla efektywności programów treningowych niezwykle ważne jest natomiast wejście $\mathrm{w}$ inny reżim żywieniowy, dlatego na profilu znaleźć można rozbudowane wpisy z przepisami kulinarnymi. W badanym okresie opublikowano sześć wpisów z przepisami na święta oraz innymi dietetycznymi przepisami. Poza niewątpliwą wartością samych wpisów były one punktem wyjścia do dyskusji wśród użytkowniczek na temat przyrządzania zdrowych posiłków, okazją do wymieniania się własnymi przepisami i udzielania porad kulinarnych. Wszystko to razem stanowiło istotny element promocji zdrowego odżywania pod auspicjami firmy. 
Jak już zauważyliśmy, posty ad hoc nie układają się żaden spójny wzór. Nie zawierają również bezpośrednich wskazań dotyczących promowanych wartości. Pośrednio możemy jednak wnioskować o niektórych z nich. Wpisy ad hoc stanowią ważny przerywnik $\mathrm{w}$ dość schematycznej komunikacji prowadzonej na profilu. Dzięki temu uzyskuje ona walor zróżnicowania i spontaniczności. Dzięki nim podrzucane są nowe, aktualne tematy. Nie są one w żaden sposób sformatowane ani dopracowane. Nierzadko są to krótkie wpisy, jak na przykład post zawierający zdjęcie palmy na Dominikanie, któremu towarzyszył wpis: „Nie będę Was męczyć tropikalnymi fotkami, ale to muszę wrzucić z zapytaniem Co przedstawia zdjęcie, które zrobiłam? Wschód słońca? Czy zachód?” (p21). Mamy tutaj do czynienia $\mathrm{z}$ dość typowym przykładem tak zwanego wpisu angażującego obliczonego na pobudzenie uwagi odbiorców. Podobnie jest w wypadku wspomnianego już zdjęcia śpiącej po treningu Chodakowskiej opatrzonego tekstem: „Lubię tak.. Czasem w białej pościeli. Czasem w szkole na materacach. Mała łajza z Bieszczad, wszędzie się odnajdzie Nio.. Gwiazdy ze mnie nie będzie. Drzemka zaliczona baterie naładowane" (p2). Wpisy tego typu mają za zadanie przełamać komunikacyjną rutynę i pobudzić uwagę publiczności. W tej kategorii znajdują się również wpisy interwencyjne. Mogą one dotyczyć podrabianych produktów (p18) lub wynikać z konieczności sprostowania nieprawdziwych informacji rozpowszechnianych w mediach (p35). Trudno określić, czy przy okazji tych ostatnich nie mamy do czynienia $\mathrm{z}$ działaniem celowym obliczonym na wywołanie kontrowersji, a przez to dynamizację komunikacji wokół profilu i zwiększenia jego zasięgu. Nie można tego jednak całkowicie wykluczyć. W badanym okresie zamieszczono również dwa posty z prośbą o wsparcie akcji charytatywnej (p28, p29). Posty te można uznać za element typowo przedświątecznej komunikacji. Inicjatywa pomocy potrzebującym dzieciom wzbudziła żywą reakcję wśród odbiorców, którzy chętnie dzielili się informacją o dokonanych wpłatach. Z drugiej strony promocja akcji na rzecz dzieci mogła być obliczona na „ocieplenie wizerunku” samej Chodakowskiej, która w odróżnieniu do wielu swoich fanek pozostaje bezdzietna.

\section{Wnioski}

Zebrany materiał skłania nas do uznania za uzasadnioną hipotezy o zasadniczym podobieństwie pomiędzy konceptualnym modelem marketingu 3.0 a strategią komunikacyjną realizowaną przez markę Ewy Chodakowskiej. Jak mogliśmy się przekonać, określenie i umocowanie wyraźnych wartości, konkretnych wizji i sposobów interpretowania rzeczywistości odgrywa w niej rolę kluczową. Misja firmy (mowa motywacyjna) będąca jej podstawowym narzędziem kulturowym służy właśnie tak zarysowanym celom. Widać wyraźnie, że ma ona trojakie znaczenie. Po pierwsze, pozwala ujawnić pewien obraz rzeczywistości, który dalej jest przedstawiany jako dominujący, oczywisty i bezdyskusyjny. Po drugie, 
przedstawia alternatywę, inny sposób jej postrzegania, proponując jednocześnie nowe reguły, na której powinna się oprzeć interpretacja otaczającego świata. Po trzecie, wskazuje komplet konkretnych narzędzi oraz sposobów realizacji owej alternatywnej wizji. Co istotne, misja ta wraz z wchodzącymi w jej skład wartościami wydaje się skutecznie znosić tradycyjną, sztywną granicę między nadawcą i odbiorcą, przyczyniając się do powstania między nimi komunikacyjnej quasi-wspólnoty. W tym sensie oferuje pole umożliwiające identyfikację celów marki z dążeniami i pragnieniami jej klientów i fanów w oparciu o abstrakcyjny zestaw wartości. Na tej podstawie wyłania się cel nadrzędny łączący markę z jej konsumentami, a także konkretne wytyczne służące jego realizacji. O swoim poparciu dla owego celu klienci mogą zaświadczyć zarówno przez zaangażowanie w działania firmy, komunikowanie i dostarczanie informacji zwrotnej, jak i dokonując zakupów. Wyraźnie też widać, że obecność misji wymaga aktywizacji po obu stronach. Jej stawką staje się wskazanie i zrozumienie wspólnego zadania, które znajduje się poza sferą czysto komercyjną. Przypadek Ewy Chodakowskiej dobrze ilustruje opisany przez Kotlera, Kartajaya i Setiawana (2010) nowy paradygmat w ramach, którego firma nie może mówić już tylko o tym, co sprzedaje i jakich korzyści dostarcza. Musi określić również, co wraz ze swoimi klientami ma zamiar osiągnąć. Tylko w ten sposób może zająć w ich życiu istotne miejsce. Dla fanek Ewy Chodakowskiej taki typ strategicznego myślenia o marce jest, jak się wydaje, całkiem atrakcyjny.

\section{Bibliografia}

Giza A. (2017), Uczeń czarnoksiężnika, czyli społeczna historia marketingu, Warszawa.

Grayson D., Nelson J. (2013), Corporate Responsibility Coalition: The Past, Present, and Future of Alliances for Sustainable Capitalism, Palo Alto.

Kotler P., Kartajaya H., Setiawan I. (2010), Marketing 3.0. Dobry produkt? Zadowolony klient? Spetniony człowiek!, przeł. D. Gasper, Warszawa.

Moscovici S. (1984), The Phenomenon of Social Representations, [w:] Social Representations, red. R. Farr, S. Moscovici, Cambridge.

Porter M.E., Kramer M.R. (2011), The Big Idea Creating Shared Value, „Harvard Business Review” 89.

Visser W. (2010), CSR 2.0: The Evolution and Revolution of Corporate Social Responsibility, [w:] Responsible Business: How to Manage a CSR Strategy Successfully, red. M. Pohl, N. Tolhurst, London.

\section{Values for sale: Building the brand image in social media}

\section{Summary}

The aim of our article is to analyze the mechanisms of value creation on the example of the brand promoted by Ewa Chodakowska, a popular fitness trainer, the owner of a company selling products and services related to physical activity. At the beginning, we describe the recent changes 
in marketing theory, with special emphasis on the concept of marketing 3.0. In the second part of the article, we analyze the material collected on Ewa Chodakowska's Facebook page and reconstruct the language and symbolic mechanisms of linking brand activity to a specific value system. As a result, we show the process of objectivation of abstract content (values) under the supervision of Ewa Chodakowska's brand. 